\title{
Inoculan Differences in the Quality of Physical and Nutrition Quality Palm Fermentation Fronds as Animal Feed
}

\author{
Tintin Rostini \\ Department of Animal Husbandry, Faculty of Agriculture, University of Islam Kalimantan \\ Jln Adyaksa No. 2 Kayu Tangi Banjarmasin- South Kalimantan, Indonesia
}

\begin{abstract}
This study aims to determine the effect of different inoculan of the physical quality and nutritional quality of fermented palm fronds. The experimental design used in this study is a randomized design complete (CRD) with 4 treatments and 3 replications, namely: T1 (palm fronds with molasis), T2 (palm fronds with strabio), T3 (palm fronds with M4 organic) and T4 (estrak palm frond with local fruit). The variables measured were: characteristics (smell, texture, color and $\mathrm{pH}$ ), content of nutrients (PK, and $S K)$ and in-vitro digestibility $(\mathrm{KCBK}$ and $\mathrm{KCBO})$. The results showed that the addition of EM4 inoculan (T3) generate the color of 2.61, by 2.87 texture, aroma with a pH of 2.67 to 3.46. The nutritional content of $32.16 \%$ crude fiber and crude protein digestibility by $7.78 \%$ whereas $70.23 \%$ of dry matter and organic matter digestibility of $68.64 \%$. It was concluded that the palm fronds can be used as ruminant feed.
\end{abstract}

Keywords: fermentation, characteristics, digestibility, palm fronds

\section{Introduction}

The growth rate of the acreage of palm oil annually in Indonesia reached $12.6 \%$ (Ardiansyah et al., 2012). It is estimated that oil palm planting area, particularly private estates and individuals will continue to grow and to this day the planting area has reached 8.1 million hectares and ranks first in the world in acreage. Indonesian CPO production increased by 6.7\% from 22 million tons to 23:30 Million tonnes (Research, 2015). The number of oil palm plantations would produce waste that is quite large. Waste oil palm plantations can be empty fruit bunches, stem, leaves, sludge, palm kernel cake / palm kernel meal (PKM) and shell..Palm frond leaves a solid waste palm oil plantations are quite a lot, from one hectare of land is estimated to be generated 6400 - 7500 midrib per year. Palm leaves contain fiber, N, organic material in an amount sufficient to support the maintenance rumiansia. Biyatmoko, (2013) Mengemukkan that feed on oil palm plantation waste consisting of palm kernel cake, palm mud, palm leaves that come from trimming palm leaf midrib ... The byproduct of oil palm plantations can not be given directly to livestock because it has a factor delimiter. (Rostini et al, 2009).Frond palm oil (Oil Palm Fronds) has been less beneficial for farmers. The trunk is hard with prickly leaves, often discarded after the oil palm fruits are old enough and should be harvested. It is necessary for feed processing technology in this case is physically processing so that leaves and fronds can be used for animal feed. Utilization of palm fronds and leaves as animal feed is expected to help overcome the problem of food availability, especially during the dry season, as well as the productivity of livestock. The purpose of this study was to determine the effect of different inoculan of the physical quality and nutritional quality of palm fronds.

\section{Material}

\section{Research Methods}

The materials used in the manufacture of fermentation include palm midrib elected, rice bran, Starbio, M4 organic, molasses and extracts of local fruits, while the tool used is a lawn mower (chopper), silo form plastic drum size of $50 \mathrm{~kg}$ by 9 fruit, plastic, wood, bamboo, plastic tape, tarps and label names

Method

Making Techniques fermentation

* fronds of palm / palm plantation waste is cut into the size of 3-5 cm, withered for 12 hours, then added bran as much as $3 \%$, which has been mixed bran midrib was then (1). strabio plus $1 \%$ per kg of forage (2). plus organic M4 as much as $1 \%$ per $\mathrm{kg}$ of forage and (3) plus the molasses $1 \%$ of the material and 4). plus local fruit extract one of the ingredients. Mixture is then inserted into the silo, compacted and covered to obtain an anaerobic atmosphere, and then cured for 21 days.

* after 21 days of fermentation and then harvested and quality tested by taking samples aseptically lab for analysis.

Experimental design

The experimental design used in this study is the complete randomized design (CRD) with 4 treatments and 3 replications, namely:

$\mathrm{T} 1=$ palm midrib with molasis 
$\mathrm{T} 2=$ palm midrib with strabio

$\mathrm{T} 3=$ palm midrib with organic M4

T4 = palm midrib with local fruit exstrack

The variables measured were: characteristics (smell, texture, color and $\mathrm{pH}$ ), content of nutrients (PK and SK) by the AOAC method (1999) and in-vitro digestibility (KCBK and KCBO)

Data analysis

How the physical presentation of data quality (characteristics) based on the scoring will be analyzed using nonparametric statistics using Kruskal Wallis test. (Steel and Torrie, 1997), while data on the nutritional quality and digestibility invitro served with descriptive and data tabulation

Physical quality of fermented palm frond

\section{Research Results}

The results of the study physical quality (texture, color, flavor and $\mathrm{pH}$ ) fermented with palm midrib with different inoculan presented in Table 1.

\section{The texture of palm frond fermentation}

The results showed significant differences among treatments $(\mathrm{P}<0.05)$ in the texture of the palm fronds. The texture highest in treatment by EM 4 (T3) of 2.67 and the lowest in treatment T1 (molasis) of 1.95. Generally four treatments showed fermentation of palm fronds with good quality, since there are no signs of damage such as destroyed or dry texture. This is due to the fermentation of palm midrib all treatment has a water content corresponding to a fermentation process ranges from $60 \%$. Rostini (2014) states that the texture of fermented palm midrib is affected by the moisture content of the material at the start of fermentation, fermentation with high water content $(>80 \%)$ showed a slimy texture, soft and moldy. While fermentai low moisture content $(<30 \%)$ have a dry texture and covered with mildew..

\section{Color palm frond fermentation}

Inoculan different usage of the color of fermented palm midrib showed significant differences among treatments $(\mathrm{P}<0.05)$. The color change produced fermented silage fermentation can dipenggaruhi by temperature, which if high temperatures can cause fermentation to brown color. Rostini et al., (2009) If the hot silo, then the resulting fermentation would be bad for the reaction "Browning", where an ugly color may occur due to organic acids such as butyric acid fermentation. Fermentation temperature can cause color change fermentation, steeper temperature caused by the presence of air in the silo as a result of the lack of good compaction or closure.

\section{The smell of fermented palm frond}

The results showed significant differences $(\mathrm{P}<0.05)$ in the palm midrib fermentation odor generated in this study, overall still good in Table 1. The best smell in treatment by EM 4 (T3) of 2.67 and the lowest in treatment (T1) of 1.25. It is the possibility of fermentation with the addition of EM4 the fermentation process is perfect so the acid produced quite a lot, namely According Rostini (2014) smell of fermentation produced properly can result in $\mathrm{pH}$ drops quickly, so it will tercipata acidic conditions that are causing the smell of fermentation smelled sour and fragrant.

\section{Palm fronds Nutrition Quality of Fermented}

Results of analysis of variance difference inoculan against fermented palm midrib showed significant differences among treatments ( $\mathrm{P}<0.05)$. It they are due the rate of growth and development of bacteria / mold varies according to the type of development. Inoculan differences influence the crude fiber content is presented in Table 1.Crude fiber content highs in treatment $\mathrm{T} 1$ (palm midrib + molasis), then decreased in treatment $\mathrm{T} 3$ (palm midrib + M4) in which EM 4 there are photosynthetic bacteria, lactic acid bacteria, which are able to accelerate reform of the organic material, liginin and cellulose so that it can reduce the content of coarse fiber material.Besides reduction in crude fiber can occur because of the decomposition process conducted by inoculan added, where the coarse fiber derived from plant cell walls that contain cellulose, hemicellulose and lignin. Howard et al., (2003) each mold that contains photosynthetic bacteria added in fermentation to produce cellulose degrading enzymes so as to reduce the content of crude fiber.

\section{Crude Potein}

The use of different inoculan significantly affect crude protein content of fermented palm midrib (P $<0.05)$. The highest crude protein on a treatment written inoculan EM4 is equal to $7.78 \%$ and the lowest in the plus molasis treatment that is equal to $5.98 \%$. Increased crude protein on a palm frond fermentation is caused by the growth of mold, which in treatment T3 (palm midrib + EM4) .Peningkatan crude protein content of palm frond fermentation due to the overhaul of organic material, which causes the degradation of crude fiber cause deterioration decline in crude fiber content so lead to increased protein content. Additionally EM 4 This contains photosynthetic bacteria, lactic acid bacteria, yeast and fungal fermentation. These photosynthetic bacteria forming substances that produce beneficial amino acids so as to increase the crude protein content of fermented 
palm midrib (Biyatmoko, 2013). Added Jonathan et al (2008) Increased rough protein content in the fermentation process probably caused the result of adding biomass to the fermentation substrate mold.

\section{Digestibility Dry Ingredients and Organic Materials}

Results showed dry matter digestibility ranged anatara $58.32 \%-70.237 \%$ and organic materials ranged between $56.74 \%-68.64 \%$. Statistical test results showed the treatment T3 has a dry matter and organic matter were significantly different $(\mathrm{P}<0.05)$ compared with other treatments $\mathrm{T} 3$ produce the digestibility of $70.23 \%$ lower compared to the treatment $\mathrm{T} 1$ digestibility rate of $58.32 \%$, The decrease in dry matter and organic matter in each treatment due to their differences in fiber content .. This is in line with Dahia et al, (2004) that the decrease in dry matter and organic matter to the level of high crude fiber content in the ration, and confirmed by Davidson et al, (2003) which suggests that the high content of crude fiber contributed to a decrease in dry matter and organic matter.

\section{Figures and Tables}

Table 1. Results Scoring physical quality of fermented palm fronds

\begin{tabular}{|l|l|l|l|l|}
\hline treatment & Texture & Color & Smell & PH \\
\hline T1 = palm fronds + molasis & $1.95^{\mathrm{a}}$ & 1.25 & 1,25 & $4,07^{\mathrm{b}}$ \\
\hline $\mathrm{T} 2=$ palm fronds + Starbio & $2,5^{\mathrm{b}}$ & 2.41 & 2,42 & $3,97^{\mathrm{b}}$ \\
\hline T3 = palm fronds + EM4 & $2.67^{\mathrm{c}}$ & 2,87 & 2,67 & $3,46 \mathrm{a}$ \\
\hline T4 = palm fronds + local fruit extracts & $2.5^{\mathrm{b}}$ & 2,42 & 2,45 & $3,84^{\mathrm{b}}$ \\
\hline
\end{tabular}

Note: Different superscript in the same column shows the effect of treatment was significantly different (P $<0.05)$

Table 2. The content of crude protein and crude and oil palm fronds fermented with different inoculan

\begin{tabular}{|l|l|l|}
\hline treatment & \multicolumn{1}{|c|}{ Serat kasar(\%) } & Protein kasar (\%) \\
\hline T1 = palm fronds + molasis & $42,32^{\mathrm{c}}$ & $5,98^{\mathrm{a}}$ \\
\hline $\mathrm{T} 2=$ palm fronds + Starbio & $40,12^{\mathrm{c}}$ & $6,14^{\mathrm{b}}$ \\
\hline $\mathrm{T} 3=$ palm fronds + EM4 & $32,16^{\mathrm{a}}$ & $7,78^{\mathrm{c}}$ \\
\hline $\mathrm{T} 4=$ palm fronds + local fruit extracts & $37,34^{\mathrm{b}}$ & $6,23^{\mathrm{b}}$ \\
\hline
\end{tabular}

Note: Different superscript in the same column shows the effect of treatment was significantly different $(\mathrm{P}$ $<0.05)$

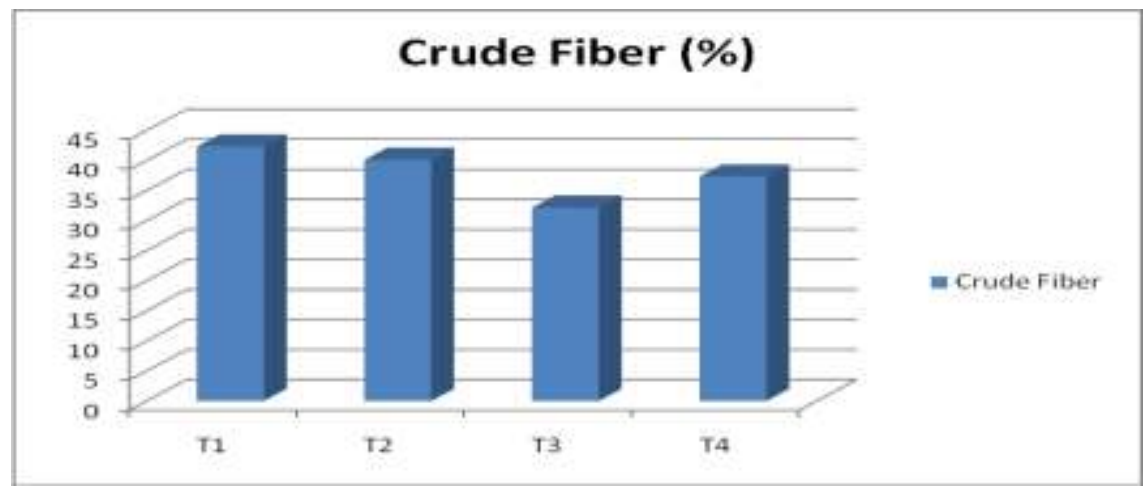

Figure 1.The curve of crude fiber content of fermented palm fronds with different inoculan

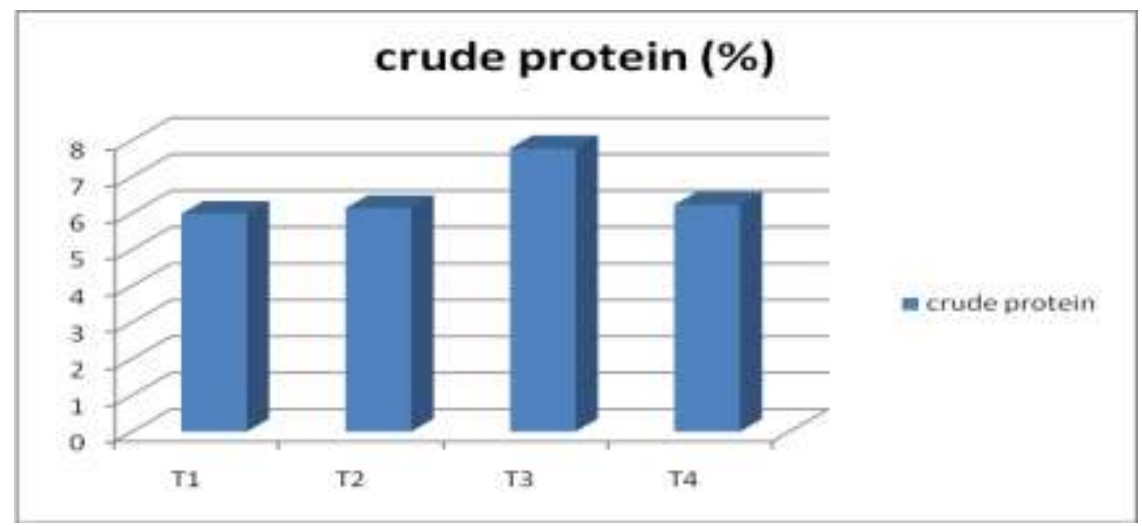

Figure 2. Curve crude protein content of palm fronds fermented with different inoculan 
Table 3. digestibility of dry matter and organic matter fermented palm frond with different inoculan

\begin{tabular}{|l|l|l|}
\hline treatment & KCBK & KCBO \\
\hline T1 = palm fronds + molasis & $58,32^{\mathrm{a}}$ & $56,74^{\mathrm{a}}$ \\
\hline $\mathrm{T} 2=$ palm fronds + Starbio & $59,06^{\mathrm{a}}$ & $57,15^{\mathrm{a}}$ \\
\hline $\mathrm{T} 3=$ palm fronds + EM4 & $70,23^{\mathrm{c}}$ & $68,64^{\mathrm{b}}$ \\
\hline T4 = palm fronds + local fruit extracts & $66,41^{\mathrm{a}}$ & $64,68^{\mathrm{b}}$ \\
\hline
\end{tabular}

Note: Different superscript in the same column shows the effect of treatment was significantly different $(\mathrm{P}$ $<0.05)$

\section{Conclusion}

Fermentation palm midrib with EM4 able to improve the physical quality of fermented palm midrib, were able to reduce the content of crude fiber and increase the crude protein content thereby increasing the digestibility of dry matter and organic matter in vitro

\section{Acknowledgements}

We would like to thank the Islamic university Kalimantan which has provided funding this research with APBU Uniska budget year 2015-2016

\section{References}

[1]. Ardiansyah,. Mulyani S, dan Fridarti. 2012. Perubahan Kandungan Nutrisi pelepah dan daun sawit melalui fermentasi dengan kapang Phanerocaete Chrysosporium. Jurnal Litbang : 23(1)

[2]. Association of Official Analytical Chemist. 1999. Official Methods of Analysis. Ed ke-16. Washington: AOAC Internationa

[3]. Biyatmoko D . 2013. The different innoculant response due to the physical and nutrition quality of corn cob fermentation as animal feeed. J. Basic Appl Sci res. 3(11):458-462.

[4]. Dahia Ds, Khatta VK, Kumar N, Mann NS. 2004. Funggal treatment of crop residues by Coprinus fimetarius and its utilization by goats. Indian J. Dairy Sci. 57:122-126

[5]. Davidson S. B.A. Hopkins D.E. Diaz, S.M. Bolt, C. Brownie, V. Fellner and L.W. Whitlow. 2003. Effects of amounts and degradability of dietrary protein on location, nitrogen utilization and excretion in early laction Holstein cows. J. Dairy Sci. 86: 1681-1689.

[6]. Dirjen Perkebunan. 2012. Perkebunan Kelapa Sawit di Indonesia. Jakarta Litbang Deptan, 2012, Pengolahan Pelepah Kelapa Sawit menjadi Pakan, http://lolitkambing.litbang.deptan.go. images/stories/pdf/pakan_komplit_pelepah_sawit.pdf, 2 Agustus2014

[7]. Howard R1., Abotsi E., Van rensburg ELJ, Howard S. 2003. Lignocellulosa biotechnology: Issues of bioconversion and enzym production . Afr.J. Biotechnol 2:602-619

[8]. Jonathan SG, Fasidi IO, Ajayi AO, Adegeye A. 2008. Biodegradation of Nigerian wood waste by pleurotus tuber-regium (Fries) Singer. Bioresource and Teknology 99:809-811

[9]. Rostini T, Zakir M, Nahrowi R, and Darobin L. 2009. Pengaruh Tingkat kadar Air yang berbeda terhadap kualitas fermentasi silase ransum komplit berbahan baku lokal. Jurnal Media Sains. Vol 1 (2): 194-202

[10]. Rostini T. 2014. Differences in chemical composition and nutrient quality of swamp forage ensiled. International Journal of Biosciences. Vol. 5(12): 145-151

[11]. Steel RGD, dan Torri JH. 1997. Prinsip dan Prosedur Statistika: Suatu Pendekatan Biometrik. Edisi II. Terjemahan : B. Sumantri PT. gramedia Pustaka Utama Jakarta. 